Gynec. Invest. 1970;1:182

\title{
To the Members of the Society of Gynecologic Investigation
}

The acceptance of Gynecologic Investigation as the official organ of our Society marks an important stage in the natural evolution of interaction and expression of this group.

Far from having been one of the founding fathers of the organization, I have nevertheless attended the meetings since 1955, when an extended round table was all that was required to accommodate all of the members and guests. In those days, the atmosphere was mostly one of friendly belligerence and the emphasis was placed on freewheeling discussions and the presentation of challenging, but not necessarily conclusive, and finished work. Those meetings were indeed something to write home about and, as a newcomer to this country, I have always considered myself fortunate to have been able to witness the development of what now must be considered the only truly representative organization of academic obstetrics and gynecology in the U.S. Just as with many others, this early association with the Society has had a profound impact on my own career and has given me a sense of loyalty which, being shared by those who believe in the function and the future of our Society, has made my affiliation with this group far more meaningful than the often perfunctory participation in other professional societies. It was to convey and kindle the spirit in our younger members and future members that Joe Seitchik, Terry Hayashi, and I had decided to ask one of our first great leaders to give us a document in the form of the Society's history. Our historian, Professor Ernie Page, of many distinctions, has kindly consented to share with us some of his experiences.

I hope that you will find in his words some of the early spirit and meaning which after all has prevailed throughout our growth and evolution.

The Editor 